\title{
Solid Waste Generation Rate in Ozamiz City, Philippines
}

\author{
Victoria E. Matunog ${ }^{1}$ and Anthony L. Awa ${ }^{2}$ \\ ${ }^{1}$ Natural Science Department, College of Arts and Sciences, Misamis University, \\ Ozamiz City, Philippines \\ ${ }^{2}$ College of Arts and Sciences, Misamis University, \\ Ozamiz City, Philippines \\ Corresponding email: victoria_elcano@yahoo.com.ph
}

\begin{abstract}
Improper waste disposal is one of the most important concerns in almost all areas in the Philippines. Republic Act (R. A.) No. 9003, otherwise known as the "Philippine Ecological Waste Management Act of 2000" required Local Government Units (LGUs) to establish a Local Government Solid Waste Management Plan (LGSWMP). Within this context, the local government of Ozamiz City in partnership with Misamis University undertook this study to gather data, on the current status of solid wastes, and to make a projection on the amount of wastes which will be collected for the next ten years. Result showed that among the four categories, biodegradable predominates followed by residual wastes. The household wastes constituted $88.9 \%$ by weight and $85.9 \%$ by volume of the total wastes. These results can be used in establishing a comprehensive and sustainable Solid Waste Management (SWM) plan which requires appropriate strategies and mechanics in addressing the problem on waste disposal.
\end{abstract}

Keywords: biodegradable, recyclable, residual, special solid wastes, waste disposal 


\section{Introduction}

Solid Waste Management remains a pressing environmental issue. Dumping of solid wastes had worsened the effects of rains, typhoons, and storms, resulting in impeding water flows and flash floods. Population growth, increased urbanization and intensified economic activities are factors that greatly affect the problem on solid waste disposal (Al-Khatib et al., 2010).

Accumulation of solid wastes in landfills exacerbates environmental problems including climate change. Solid wastes contribute to climate change by increasing greenhouse gases such as methane $\left(\mathrm{CH}_{4}\right)$, emitted from landfills where the waste is disposed while carbon dioxide $\left(\mathrm{CO}_{2}\right)$ and nitrous oxide $\left(\mathrm{N}_{2} \mathrm{O}\right)$ emitted from waste combustion (IETC, 2010). Water pollution is another issue as leachate generated from landfill can contain pollutants that will deteriorate water quality. Vasanthi (2008) showed that high concentration of total dissolved solids, electrical conductivity, hardness, nitrates, chlorides, sulphates, in ground water near landfill area made the water unfit for drinking.

Reduction of solid waste generation rate is at the top of solid waste management practices. The general global consensus points out that the climate benefits of waste avoidance and recycling far outweigh the benefits from any waste treatment technology, even where energy is recovered during the process (IETC, 2010). The quantity and composition of the waste streams enable policy and decision makers to identify problems within the existing waste management practices, as well as determining waste reduction tools and initiatives, and the feasibility of setting up recovery and recycling systems (Sagapolutele \& Rasch, 2008).

In the Philippines, Republic Act (R. A.) No. 9003, otherwise known as the "Philippine Ecological Waste Management Act of 2000", required local government units to establish a Local Government Solid Waste Management Plan (LGSWMP). The Ecological Solid Waste Management (ECOSWAM) Act, which emanated from R. A. No. 9003, obliged municipalities to dispose waste in a sanitary and environmentally friendly manner (Naz \& Naz, 2008). Within this context, the Department of Environment and Natural Resources (DENR) issued Administrative Order No. 2001 - 
34 in 2001, otherwise known as the implementing rules and regulations (IRR) of the provisions of R. A. No. 9003 that laid down procedures and guidelines to the implementation of the solid waste management (SWM) plan. A sustainable SWM required research undertaking (DENR, 2001) which covers waste analysis and characterization study (WACS).

Ozamiz City as an emerging commercial center in Mindanao (Artajo, 2007) has an annual population growth rate of 1.55 percent for the last ten years (2000-2010) (NSO, 2013). The city is composed of 51 barangays of which only 23 (urban coastal/lowland/business and residential barangays) availed of the city waste collection services. It has a dumpsite located in Brgy. Bongbong, Ozamiz City. The other 27 rural and less populated barangays used indigenous/acquired solid wastes management system due to distance and budgetary constraints.

In response to R. A. No. 9003, the Ozamiz City Local Government in partnership with Misamis University, undertook a solid waste generation rate study. This study aimed to establish possible projections, which can be utilized for planning future mechanisms, procurement of facilities, landfill development and cost estimates to be incorporated in the integrated SWM plan of the city.

\section{Materials and Methods}

\section{Collections Procedure}

The study was conducted in Ozamiz City, Philippines in November 2012. This covered the 23 barangays which availed the city waste collection services. The waste generators were identified as households and non-households. The household sources were categorized according to income status namely: high, middle and low income. Twenty households were selected to represent each category. The non-household sources were categorized into: a) Ozamiz City Public Market; b) business establishments: fast food outlets, restaurants, bakeries, general stores, agricultural shops; c) industries; d) institutions: government offices, private and business offices, churches, schools; e) service establishments: hotels, inns, terminals, beauty parlors, gasoline stations, pawnshops, gas stations, copiers, printing shops; f) recreation centers: internet cafés, coliseum, gymnasium, entertainment centers; g) health related facilities: 
hospitals, laboratories, clinics, pharmacies; and h) dormitories, boarding houses. Each group was categorized as big, medium or small based on the listing in the Office of Permit and Licensing Division of the city. Three to six representatives were selected for each category.

This undertaking was done following the general guidelines and procedures in conducting waste characterization survey (Briones, 2011). Solid wastes were classified as biodegradable, recyclable, residual and special wastes. From each of the identified sample sources, the wastes were collected for three consecutive days. Prior to collection, three pre-weighed bags labelled with biodegradable, recyclable and residual respectively, were allotted every day to which the wastes were placed separately. Another pre-weighed bag was allocated for special wastes, which was collected only on the third day.

At the sample processing site, in a vacant area within the Ozamiz City Integrated Bus and Jeepney Terminal (IBJT), all sample wastes collected and placed in different pre-weighed plastic bags (for biodegradable, recyclable and residual and special wastes) were weighed and checked/sorted for possible mixture of other waste types. Wastes that were mixed were removed and transferred to their respective bags and re-weighed to determine the weight for the respective waste character/composition generated per source.

\section{Data Analysis}

Daily average weight and volume of solid wastes generation rate per household, and subsequently per individual, were calculated. Mathematical projections on daily and annual waste generations for household sources, for the years 2012 - 2022, were computed using the average annual population growth of 1.55 (NSO, 2013).

Daily average weight and volume of solid wastes generation rate per nonhousehold category, and subsequently per establishment in a category, were calculated. The mathematical projections on waste generations for all nonhousehold sources were based on the 2012 listings of commercial and institutional establishments provided by the city's Permit and Licensing Division. The projected average increase of establishment (8\%) was obtained utilizing the increase from 20102011 multiplied with the total number of establishment as of 2012. (see formula) 


$$
A W_{d}=\frac{W_{1}+W_{2}+W_{3}+\cdots W_{n}}{N}
$$

Where: $\mathrm{AW}_{\mathrm{d}}=$ average weight of wastes per category per day

$\mathrm{W}=$ weight of wastes per day collection

$\mathrm{N}=$ number of days

$A W_{I / d}=\frac{\left(A W_{d}\right)_{1}+\left(A W_{d}\right)_{2}+\left(A W_{d}\right)_{3}+\cdots\left(A W_{d}\right)_{n}}{P_{1}+P_{2}+P_{3}+\cdots P_{n}} \quad$ (for household sources)

Where: $\mathrm{AW}_{\mathrm{I} / \mathrm{d}}=$ Average weight of wastes per individual per day

$\mathrm{P}=$ population per category

$\mathrm{n}=$ number of categories

$A W_{c / d}=\frac{A W_{d}}{N}$

(for nonhousehold sources)

Where: $\mathrm{AW}_{\mathrm{c} / \mathrm{d}}=$ Average weight of wastes per nonhousehold source category per day

$\mathrm{N}$ = number of establishments per nonhousehold category

$W_{s / d}=(P G R)\left(P_{p}\right)\left(W_{I / d}\right)+\left(W_{p / d}\right)$

Where: $\mathrm{W}_{\mathrm{s} / \mathrm{d}}=$ weight per day of the succeeding year

PGR = population growth rate (or projected growth rate of nonhousehold sources)

$\mathrm{Pp}=$ Population ( or number of establishments in a nonhousehold category) of the preceding year

$\mathrm{W}_{\mathrm{p} / \mathrm{d}}=$ weight per day of the preceding year

$\mathrm{W}_{\mathrm{I} / \mathrm{d}}=\mathrm{W}_{\mathrm{c} / \mathrm{d}}($ for nonhousehold sources $)$

$W_{s / a}=\left(W_{s / d}\right)(365$ days $)$

(for household sources)

$W_{s / a}=\left[\left(W_{(s / d)_{1}}\right)+\left(W_{(s / d)_{2}}\right)+\cdots\left(W_{(s / d)_{n}}\right)\right][365$ days $]$

(for nonhousehold sources)

Where: $\mathrm{W}_{\mathrm{s} / \mathrm{a}}=$ total weight for the succeeding year $\mathrm{n}=$ number of nonhousehold source categories

Note: Projection on volume was done using the same formula, but the weight (W) was replaced with volume (V). 


\section{Results and Discussion}

Results show that household solid wastes consist substantially of waste materials coming from diverse sources. Among the three household sources categories (high, middle and low income), it was found out that low income households have the highest percentage contribution to wastes. However, when calculated per capita, both low and high income categories had the same generation rate. In this study, the generation rate disagreed with the findings of Haider et al. (2013), which showed that high income household generates more wastes than the low and middle income households. Table 1 shows the solid waste generation rate from household sources by weight $(\mathrm{kg})$ and volume (L).

Table 1. Composition by weight $(\mathrm{kg})$ and volume $(\mathrm{L})$ of the solid wastes generated from household sources.

\begin{tabular}{lcccc}
\hline \hline $\begin{array}{c}\text { Household } \\
\text { Categories }\end{array}$ & $\begin{array}{c}\text { Average Daily } \\
\text { Weight } \\
\text { (kg/per } \\
\text { Household) }\end{array}$ & $\begin{array}{c}\text { Average Daily } \\
\text { Weight } \\
\text { (kg per } \\
\text { Individual) }\end{array}$ & $\begin{array}{c}\text { Average Daily } \\
\text { Volume } \\
\text { (L per } \\
\text { Household) }\end{array}$ & $\begin{array}{c}\text { Average Daily } \\
\text { Volume } \\
\text { (L per } \\
\text { Individual) }\end{array}$ \\
\hline Low Income & 5.1 & 0.73 & 19.89 & 2.73 \\
Middle Income & 3.62 & 0.7 & 16.49 & 2.84 \\
High Income & 3.2 & 0.73 & 13.61 & 3.24 \\
Total & 11.92 & 2.16 & 49.99 & 8.81 \\
Average & 3.97 & 0.72 & 16.66 & 2.94 \\
\hline \hline
\end{tabular}

Solid wastes obtained were characterized as biodegradable/compostable- these are wastes that undergo biological degradation under controlled conditions and can be turned into compost by mixing it with soil, water, air and biological additives (e.g. food waste, garden waste, animal waste and human waste); recyclablerefer to any waste material retrieved from the waste stream and free from contamination that can be further converted into beneficial use. These are materials that can be still transformed into new products in such a manner that the original products may lose their identity (e.g. papers boxes, plastic materials, newspaper, ferrous scrap metal, nonferrous scrap metal, corrugated cardboard, aluminum, glass, office papers and tin cans); residual wastes - are solid wastes that are noncompostable and non-recyclable. These are wastes that need to be 78 
disposed ecologically through a long-term disposal facility or sanitary landfill (e.g. sanitary napkins, disposable diapers, worn-out rugs, ceramics, candy wrappers/sachets, cartons, which contain a plastic lining usually used for milk and juice containers); and special wastesrefer to household hazardous wastes (e.g. paints, thinners, batteries, spray canisters, wires, broken appliances and consumer electronics) (US EPA, 1996). Table 2 shows the solid waste composition from different household sources as characterized into four wastes categories. Biodegradable wastes have the highest contribution to the total solid wastes generated. This can be favorable to the community, as long as the technology to convert these materials into other products, such as fertilizers, is in place. However, of utmost concern are the residual wastes thrown into dumpsite, because an inevitable trend as seen in many developing countries is the uncontrolled tipping/open dumping of wastes which can still produce high hazards to the environment (Oeltzschner \& Mutz, 1994). These include contamination of ground water, scattering of waste by wind and scavenging animals; bad smells and danger of burning which produce smoke that can be very dangerous to the health; breeding vermin and pests; organic waste gases produced through decomposition: mainly carbon dioxide, methane, small amounts of hydrogen sulfide and other gases (Oeltzschner \& Mutz, 1994; Rasi et al., 2007). In this study, the generation rate of residual wastes in Ozamiz City per capita was 0.242 $\mathrm{kg}$ by weight and $0.0863 \mathrm{~L}$ by volume.

\section{Table 2. Composition by weight (kg) and volume ( $L$ ) of solid wastes generated per household and per individual.}

Composition of Waste (Household) Biodegradable Recyclable Residual Special Total

\begin{tabular}{lccccc}
\hline Ave. Daily Weight / HH (kg) & 2.06 & 0.56 & 1.34 & 0.02 & 3.97 \\
Ave. Daily Weight/Individual (kg) & 0.373 & 0.101 & 0.242 & 0.004 & 0.72 \\
Ave. Daily Weight/Individual (grams) & 373 & 101 & 242 & 4 & 720 \\
Percentage Composition by Weight (\%) & 51.82 & 14.04 & 33.63 & 0.51 & 100 \\
Ave. Daily Volume/ HH (L) & 6.63 & 5.12 & 4.89 & 0.02 & 16.66 \\
Ave. Daily Volume/Individual (L) & 1.171 & 0.903 & 0.863 & 0.004 & 2.94 \\
Ave. Daily Volume/Individual (cc) & 1171 & 903 & 863 & 4 & 2940 \\
Percentage Composition by Volume (\%) & 39.82 & 30.71 & 29.35 & 0.12 & 100 \\
\hline \hline
\end{tabular}


In addition, the waste generation rates from non-household sources are shown in Table 3 reflecting the average total weight produced and the percent composition of the waste as to biodegradable, recyclable, residual and special wastes. From each of the sampled sources, biodegradable and residual waste components constituted the great bulk of the waste. The public market produced the highest amount of biodegradable waste. Universities and food establishments which ranked second and third respectively, generated far lower than the public market. The good part is that such materials can be converted to organic fertilizers with the aid of advance technology to ascertain the quality of the product. Moreover, the use of Materials Recovery Facility (MRF) which receives, processes, sorts and typically bale diverts recyclable materials is equally important to advance recycling facility. However, prior to the recycling process, checking on proper segregation should be done appropriately because it was noted that individual waste generators had trouble in identifying special or hazardous wastes, in the event, some were mixed with the other wastes categories.

The residual waste materials will reach the dumpsite or landfill given that proper waste disposal management is in place. However, these wastes shall scatter as litter if unregulated dumping is permitted. If the city will not provide efficient recycling facilities, in like manner, recyclable wastes will either enter into the dumpsite/landfill or even scatter (McCormack, 2004). In this study, the university was the top producer of recyclable materials where most of the wastes were related to instruction process.

Table 3. Composition by weight (kg) of the solid wastes generated daily from non-household sources.

\begin{tabular}{lcccccccccc}
\hline \hline \multirow{2}{*}{ Waste Source } & \multicolumn{2}{c}{ Biodegradable } & \multicolumn{2}{c}{ Recyclable } & \multicolumn{2}{c}{ Residual } & \multicolumn{2}{c}{ Special } & \multicolumn{2}{c}{ Total } \\
\cline { 2 - 11 } & $\mathrm{Wt}(\mathrm{kg})$ & $\%$ & $\mathrm{Wt}(\mathrm{kg})$ & $\%$ & $\mathrm{Wt}(\mathrm{kg})$ & $\%$ & $\mathrm{Wt}(\mathrm{kg})$ & $\%$ & $\mathrm{Wt}(\mathrm{kg})$ & $\%$ \\
\hline $\begin{array}{l}\text { a) Public Market } \\
\text { b) Business Establishments }\end{array}$ & $1,739.30$ & 59.2 & 0.00 & 0.0 & $1,201.30$ & 40.8 & 0.00 & 0.0 & $2,940.60$ & 100.0 \\
1) Food Establishments (LS) & 114.30 & 84.0 & 3.50 & 2.6 & 18.10 & 13.4 & 0.01 & 0.0 & 135.90 & 100.0 \\
$\quad$ Food Establishments (MS) & 9.30 & 58.1 & 1.00 & 6.3 & 5.70 & 35.6 & 0.00 & 0.0 & 16.05 & 100.0 \\
$\quad$ Food Establishments (SS) & 3.14 & 59.7 & 1.62 & 30.7 & 0.50 & 9.5 & 0.00 & 0.0 & 5.26 & 100.0 \\
2) Bakeshops & 3.00 & 40.9 & 0.40 & 5.4 & 4.00 & 53.7 & 0.00 & 0.0 & 7.39 & 100.0 \\
3) General Stores (LS) & 24.90 & 57.7 & 6.70 & 15.5 & 11.60 & 26.9 & 0.00 & 0.0 & 43.20 & 100.0 \\
\hline \hline
\end{tabular}


Table 3. Continued: Composition by weight $(\mathrm{kg})$ of the solid wastes generated daily from non-household sources.

\begin{tabular}{|c|c|c|c|c|c|c|c|c|c|c|}
\hline \multirow{2}{*}{ Waste Source } & \multicolumn{2}{|c|}{ Biodegradable } & \multicolumn{2}{|c|}{ Recyclable } & \multicolumn{2}{|c|}{ Residual } & \multicolumn{2}{|c|}{ Special } & \multicolumn{2}{|c|}{ Total } \\
\hline & $\mathrm{Wt}(\mathrm{kg})$ & $\%$ & $\mathrm{Wt}(\mathrm{kg})$ & $\%$ & $\mathrm{Wt}(\mathrm{kg})$ & $\%$ & $\mathrm{Wt}(\mathrm{kg})$ & $\%$ & $\mathrm{Wt}(\mathrm{kg})$ & $\%$ \\
\hline General Stores (MS) & 3.50 & 78.5 & 0.40 & 9.6 & 0.05 & 11.9 & 0.00 & 0.0 & 4.40 & 100.0 \\
\hline General Stores (SS) & 0.50 & 36.9 & 0.10 & 7.1 & 0.80 & 56.0 & 0.00 & 0.0 & 1.40 & 100.0 \\
\hline 4) Hardwares & 0.64 & 39.8 & 0.05 & 3.1 & 0.88 & 55.0 & 0.01 & 2.4 & 1.60 & 100.0 \\
\hline 5) Agricultural Supplies & 0.63 & 46.0 & 0.38 & 27.7 & 0.36 & 26.3 & 0.00 & 0.0 & 1.37 & 100.0 \\
\hline c.) Industries & 3.10 & 19.0 & 3.10 & 18.7 & 10.20 & 62.0 & 0.05 & 0.3 & 16.39 & 100.0 \\
\hline \multicolumn{11}{|l|}{ d.) Institutions } \\
\hline 1) Government Institutions & 4.20 & 71.9 & 0.60 & 10.3 & 1.00 & 17.2 & 0.03 & 0.6 & 5.82 & 100.0 \\
\hline 2) Churches & 6.30 & 69.5 & 1.30 & 14.3 & 1.50 & 16.0 & 0.02 & 0.2 & 9.09 & 100.0 \\
\hline 3) Learning Centers & 2.30 & 59.0 & 0.30 & 6.8 & 1.30 & 34.2 & 0.00 & 0.0 & 3.87 & 100.0 \\
\hline $\begin{array}{l}\text { 4) Schools: Elem. \& High } \\
\text { Sch. }\end{array}$ & 7.30 & 56.6 & 3.80 & 29.1 & 1.30 & 10.0 & 0.57 & 4.3 & 12.97 & 100.0 \\
\hline 5) Universities & 133.30 & 70.2 & 16.90 & 8.9 & 39.20 & 20.6 & 0.61 & 0.3 & 189.97 & 100.0 \\
\hline \multicolumn{11}{|l|}{ e. Service Establishments } \\
\hline 1) Hotels/Inn & 4.90 & 55.6 & 2.00 & 22.2 & 2.00 & 22.2 & 0.00 & 0.0 & 8.79 & 100.0 \\
\hline 2) Barbers/ & 1.00 & 35.3 & 0.50 & 17.7 & 1.30 & 45.9 & 0.03 & 1.1 & 2.76 & 100.0 \\
\hline 3) Shops/Gas Stations & 3.40 & 75.6 & 0.50 & 11.1 & 0.60 & 13.3 & 0.00 & 0.0 & 4.42 & 100.0 \\
\hline 4) Pawnshops & 0.80 & 67.0 & 0.10 & 9.6 & 0.10 & 8.5 & 0.00 & 0.0 & 1.00 & 100.0 \\
\hline 5) Copier/Printing Shops & 2.70 & 87.0 & 0.00 & 0.0 & 0.40 & 12.8 & 0.01 & 0.2 & 3.05 & 100.0 \\
\hline \multicolumn{11}{|l|}{ f. Recreation Centers } \\
\hline 1) Internet Cafés & 0.50 & 21.7 & 0.70 & 30.4 & 1.10 & 47.8 & 0.00 & 0.0 & 2.30 & 100.0 \\
\hline 2) Parks/Centers & 18.00 & 71.7 & 3.30 & 13.2 & 3.80 & 15.1 & 0.00 & 0.0 & 25.10 & 100.0 \\
\hline 3) Coliseum/ Gym & 8.10 & 60.8 & 2.10 & 15.6 & 3.10 & 23.6 & 0.00 & 0.0 & 13.30 & 100.0 \\
\hline 4) Entertainment & 11.10 & 59.4 & 1.30 & 7.0 & 6.30 & 33.7 & 0.00 & 0.0 & 18.70 & 100.0 \\
\hline \multicolumn{11}{|l|}{ g. Health Related Facilities } \\
\hline 1) Tertiary Hospitals & 5.80 & 60.4 & 1.50 & 15.0 & 2.40 & 25.0 & 0.00 & 0.0 & 9.60 & 100.0 \\
\hline 2) Secondary Hospitals & 1.29 & 41.6 & 0.25 & 6.8 & 1.60 & 51.6 & 0.00 & 0.0 & 3.10 & 100.0 \\
\hline 3) Clinics/Laboratories & 1.30 & 72.2 & 0.30 & 16.7 & 0.20 & 11.1 & 0.00 & 0.0 & 1.80 & 100.0 \\
\hline 4) Pharmacy & 3.40 & 71.8 & 0.10 & 2.7 & 1.20 & 25.5 & 0.00 & 0.0 & 4.70 & 100.0 \\
\hline \multicolumn{11}{|l|}{ h. Boarding Houses/Dormitories } \\
\hline 1) Boarding Houses (Small) & 0.47 & 31.5 & 0.35 & 23.6 & 0.63 & 0.4 & 0.03 & 2.3 & 1.48 & 100.0 \\
\hline 2) Boarding houses (M) & 3.18 & 69.0 & 0.37 & 8.0 & 1.06 & 23.0 & 0.00 & 0.0 & 4.60 & 100.0 \\
\hline 3) Dormitories & 6.69 & 75.0 & 0.38 & 4.0 & 1.82 & 20.0 & 0.02 & 0.2 & 8.90 & 100.0 \\
\hline
\end{tabular}

LS-large scale; MS-medium scale; SS-small scale 
Table 4 presents the volume and composition of the nonhousehold wastes. Volume and weight are important components for proper estimation of the quantities and composition of the waste stream. The underestimation of solid waste generation rate may shorten landfill life due to overloading. The nature and quantity of waste accepted at the landfill shall determine possible control measures required in designing a landfill (Carey, 2000). Measured by volume, this study revealed that, biodegradable and residual solid wastes were higher than non-biodegradable and special wastes. In volume, the public market was the top biodegradable and residual waste generator, followed by universities with a significant difference. Food establishments, which ranked third when wastes were measured by weight, ranked fourth. This showed that solid wastes from the public market and universities were bulkier than those from food establishments.

Table 4. Composition by volume (L) of the solid wastes generated daily from non-household sources.

\begin{tabular}{|c|c|c|c|c|c|c|c|c|c|c|}
\hline \multirow{2}{*}{ Waste Source } & \multicolumn{2}{|c|}{ Biodegradable } & \multicolumn{2}{|c|}{ Recyclable } & \multicolumn{2}{|c|}{ Residual } & \multicolumn{2}{|c|}{ Special } & \multicolumn{2}{|c|}{ Total } \\
\hline & $\operatorname{vol}(\mathrm{L})$ & $\%$ & $\operatorname{vol}(\mathrm{L})$ & $\%$ & $\operatorname{vol}(\mathrm{L})$ & $\%$ & $\operatorname{vol}(\mathrm{L})$ & $\%$ & $\operatorname{vol}(\mathrm{L})$ & $\%$ \\
\hline a) Public Market & $15,684.00$ & 59.1 & 0.00 & 0.0 & $10,812.00$ & 40.9 & 0.00 & 0.02 & $26,466.00$ & 100.0 \\
\hline \multicolumn{11}{|l|}{ b) Business Establishments } \\
\hline 1) Food establishments (LS) & 29.80 & 47.5 & 10.30 & 16.4 & 22.70 & 36.1 & 0.00 & 0.0 & 62.00 & 100.0 \\
\hline Food Establishments (M S) & 29.70 & 68.8 & 5.30 & 12.3 & 7.84 & 18.2 & 0.30 & 0.7 & 43.14 & 100.0 \\
\hline Food Establishments (SS) & 9.50 & 32.0 & 17.70 & 59.7 & 2.50 & 8.4 & 0.00 & 0.0 & 29.70 & 100.0 \\
\hline 2) Bakeshoppe & 8.80 & 31.1 & 4.00 & 14.1 & 15.60 & 54.8 & 0.00 & 0.0 & 28.40 & 100.0 \\
\hline 3). General Stores (LS) & 92.20 & 47.4 & 32.70 & 16.8 & 69.50 & 35.8 & 0.00 & 0.0 & 194.40 & 100.0 \\
\hline General Stores (MS) & 12.60 & 76.6 & 2.30 & 13.9 & 1.60 & 9.5 & 0.00 & 0.0 & 16.40 & 100.0 \\
\hline General Stores (SS) & 4.50 & 39.1 & 2.20 & 18.8 & 4.80 & 42.0 & 0.00 & 0.0 & 11.50 & 100.0 \\
\hline 4) Hardwares & 7.70 & 54.4 & 0.20 & 1.2 & 6.30 & 44.6 & 0.00 & 0.0 & 14.20 & 100.0 \\
\hline 5) Agricultural Supplies & 5.00 & 53.2 & 1.20 & 13.0 & 3.20 & 34.3 & 0.00 & 0.0 & 9.40 & 100.0 \\
\hline c. Industries & 13.90 & 18.4 & 17.00 & 22.5 & 44.50 & 58.9 & 0.20 & 0.3 & 75.60 & 100.0 \\
\hline \multicolumn{11}{|l|}{ d. Institutions } \\
\hline 1) Gov't Inst/Office/Banks & 21.80 & 63.9 & 4.40 & 12.9 & 7.84 & 23.0 & 0.06 & 0.2 & 34.10 & 100.0 \\
\hline 2) Churches & 20.60 & 54.4 & 9.10 & 24.0 & 8.10 & 21.4 & 0.10 & 0.3 & 37.90 & 100.0 \\
\hline 3. Learning Centers & 11.70 & 42.7 & 3.80 & 14.0 & 11.80 & 43.3 & 0.00 & 0.0 & 27.30 & 100.0 \\
\hline
\end{tabular}




\section{Table 4. Continued: Composition by volume (L) of the solid wastes generated daily from non-household sources.}

\begin{tabular}{|c|c|c|c|c|c|c|c|c|c|c|}
\hline \multirow{2}{*}{ Waste Source } & \multicolumn{2}{|c|}{ Biodegradable } & \multicolumn{2}{|c|}{ Recyclable } & \multicolumn{2}{|c|}{ Residual } & \multicolumn{2}{|c|}{ Special } & \multicolumn{2}{|c|}{ Total } \\
\hline & $\operatorname{vol}(\mathrm{L})$ & $\%$ & $\operatorname{vol}(\mathrm{L})$ & $\%$ & $\operatorname{vol}(\mathrm{L})$ & $\%$ & $\operatorname{vol}(\mathrm{L})$ & $\%$ & $\operatorname{vol}(\mathrm{L})$ & $\%$ \\
\hline 4) Schools & 31.50 & 54.1 & 16.90 & 29.0 & 9.50 & 16.3 & 0.30 & 0.5 & 58.20 & 100.0 \\
\hline 5) Universities & 524.20 & 61.4 & 151.30 & 17.7 & 177.80 & 20.8 & 0.50 & 0.1 & 853.80 & 100.0 \\
\hline \multicolumn{11}{|l|}{ e. Service Establishments } \\
\hline 1) Hotels/Inn & 13.30 & 33.7 & 18.80 & 47.5 & 7.40 & 18.8 & 0.00 & 0.0 & 39.60 & 100.0 \\
\hline 2) Barbers/Saloon & 6.60 & 38.4 & 4.83 & 28.1 & 5.77 & 33.6 & 0.00 & 0.0 & 17.20 & 100.0 \\
\hline 3) Shops/Gas Stations & 8.10 & 49.1 & 3.30 & 19.9 & 5.10 & 31.0 & 0.00 & 0.0 & 16.50 & 100.0 \\
\hline 4) Pawnshops & 4.30 & 61.3 & 1.90 & 26.7 & 0.80 & 12.0 & 0.00 & 0.0 & 6.90 & 100.0 \\
\hline 5) Copier/Printing Shops & 22.90 & 84.1 & 0.00 & 0.0 & 4.30 & 15.8 & 0.03 & 0.1 & 27.23 & 100.0 \\
\hline \multicolumn{11}{|l|}{ f. Recreational Centers } \\
\hline 1) Internet Cafés & 2.50 & 23.2 & 2.90 & 27.2 & 5.30 & 49.6 & 0.00 & 0.0 & 10.80 & 100.0 \\
\hline 2) Parks/Centers & 43.00 & 48.7 & 25.70 & 29.1 & 19.70 & 22.3 & 0.00 & 0.0 & 88.30 & 100.0 \\
\hline 3) Coliseum/ Gymnasium & 32.20 & 44.1 & 15.70 & 21.5 & 25.10 & 34.4 & 0.00 & 0.0 & 73.00 & 100.0 \\
\hline 4) Entertainment & 26.00 & 50.2 & 8.30 & 16.1 & 17.50 & 33.8 & 0.00 & 0.0 & 51.80 & 100.0 \\
\hline \multicolumn{11}{|c|}{ g. Health Related Facilities: Hospitals / Laboratories / Clinics } \\
\hline 1) Tertiary Hospitals & 22.60 & 48.8 & 9.80 & 21.2 & 13.90 & 30.0 & 0.00 & & 46.30 & 100.0 \\
\hline 2) Secondary Hospitals & 6.30 & 45.3 & 3.30 & 23.7 & 4.30 & 30.9 & 0.00 & 0.0 & 13.90 & 100.0 \\
\hline 3) Clinics/laboratories & 4.60 & 46.4 & 2.90 & 29.3 & 2.40 & 24.2 & 0.00 & 0.0 & 9.90 & 100.0 \\
\hline 4) Pharmacy & 24.50 & 65.9 & 0.80 & 2.2 & 11.80 & 31.8 & 0.00 & 0.0 & 37.20 & 100.0 \\
\hline \multicolumn{11}{|c|}{ h. Boarding Houses/Dormitories } \\
\hline 1) Boarding Houses (SS) & 3.33 & 46.5 & 0.53 & 7.4 & 3.20 & 44.7 & 0.10 & 1.4 & 7.16 & 100.0 \\
\hline 2) Boarding Houses (MS) & 7.17 & 18.2 & 12.83 & 32.6 & 19.33 & 49.2 & 0.00 & 0.0 & 39.33 & 100.0 \\
\hline 3) Dormitories (LS) & 18.83 & 52.7 & 7.17 & 20.1 & 9.65 & 26.6 & 0.05 & 0.6 & 35.70 & 100.0 \\
\hline
\end{tabular}

LS-large scale; MS-medium scale; SS-small scale

The daily percentage composition of wastes by weight and volume for both household and non-household sources is shown in Figures 1 and 2 respectively. Majority of the wastes were biodegradable followed by the residual wastes. In this view, proper management of such wastes with the provision of composting facility will benefit the populace by providing additional income and preventing accumulation of wastes in the dumping site. 


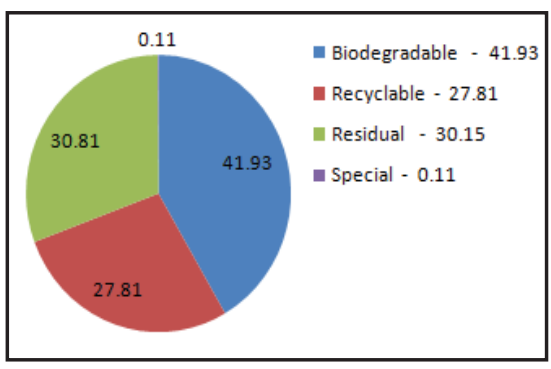

Figure 1. Percentage composition of daily wastes by weight both household and nonhousehold

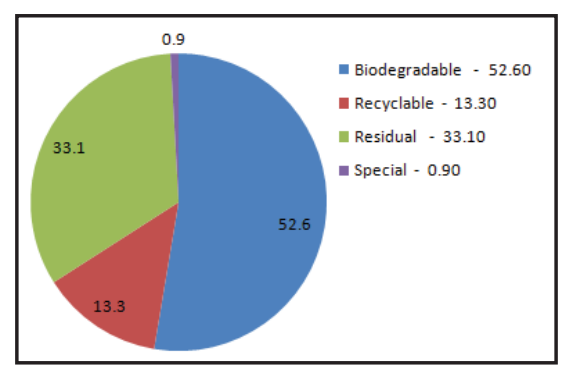

Figure 2. Percentage composition of daily wastes by volume both household and nonhousehold

Moreover, Table 5 shows the annual projection on solid waste generation in Ozamiz City where, the total weight of daily generated solid wastes may amount to 85.15 tons. This constitutes a volume of $36.24 \mathrm{~m}^{3}$ per day. Computed on an annual basis, the total waste generated from all the sources will be 31,079.78 tons with a total volume of $13,229.65 \mathrm{~m}^{3}$ annually. Here, majority of the wastes were generated from household sources. Accounting for this could be the increasing rate of population growth and economic development in urban areas, which may lead to an increase in wastes generation (Ogbonna et al., 2007; Ramachandra \& Bachamanda, 2007). The amount of waste could aggravate and may both be hard and expensive to manage. In this regard, the management capability of most of the solid waste management systems that may deal with the increasing volume of waste and its changing characteristics in almost all areas has to be necessarily enhanced due to overwhelming overpopulation and economic affluence (Ogbonna et al., 2007). A World Bank study showed that urban areas in Asia spent USD25 million per year on solid waste management, and this figure will increase to USD47 million per year. However, despite the huge expenditures, the problem on environmental degradation due to non-systematic solid waste management still persists (Environmental Management Centre, 2007). For instance, the waste disposal system of Ozamiz City, spearheaded by the local government will impose considerable financial stress on the treasury of the local government if proper segregation is not performed at the household level or point of generation. Proper wastes 
segregation is perceived to help facilitate the processing of wastes and substantially decrease the amount of wastes directed to the dumpsite. Hence, source segregation will reduce costs which are related to waste collection and transport, the most expensive element in the total process of current waste management (Nasrabadi et al., 2008).

\section{Table 5. Annual projection on solid waste generation in Ozamiz City.}

\begin{tabular}{|c|c|c|c|c|c|c|}
\hline \multirow{2}{*}{ Vaste Source } & \multicolumn{2}{|c|}{ Total (Daily) } & \multicolumn{2}{|c|}{ Total (Annually) } & \multicolumn{2}{|c|}{ Total (Annually) } \\
\hline & Wt $(\mathrm{kg})$ & Vol (L) & $\mathrm{Wt}(\mathrm{kg})$ & $\operatorname{Vol}(\mathrm{L})$ & tons & $\mathrm{m}^{3}$ \\
\hline $\begin{array}{l}\text { TOTAL } \\
\quad \text { (HOUSEHOLDS) }\end{array}$ & $(75,723.84)$ & $(311,309.12)$ & $(27,639,201.60)$ & 28.80) & $(27,639.20)$ & $(1136.28)$ \\
\hline \multicolumn{7}{|l|}{ Non-Household Sources } \\
\hline a. Public Market & $2,940.60$ & 26, & 1,073, & 00 & 1,0 & 967.1 \\
\hline $\begin{array}{l}\text { b. Business } \\
\text { Establishments }\end{array}$ & $3,016.16$ & 0 & $1,100,898.40$ & $3,220,395.00$ & $1,100.90$ & 322.04 \\
\hline c. Industries & 350.91 & $1,585.50$ & 128082.15 & $578,707.50$ & 128.08 & 57.8 \\
\hline d. Institutions & $1,609.61$ & $7,132.80$ & $587,507.60$ & $2,603,472.00$ & 587.51 & 260.3 \\
\hline $\begin{array}{l}\text { e. Service } \\
\text { Establishments }\end{array}$ & 672.00 & 3271.8 & $245,280.00$ & 1194207 & 245.28 & 119.42 \\
\hline f. Recreation Centers & 333.40 & 1312.2 & $121,691.00$ & 478953 & 121.69 & 47 \\
\hline $\begin{array}{l}\text { g. Health Related } \\
\text { Facilities }\end{array}$ & 216.42 & 1399.5 & $78,993.30$ & 510817.5 & 78.99 & 51. \\
\hline $\begin{array}{l}\text { h. Boarding } \\
\text { House/Dormitories }\end{array}$ & 287.15 & 1126.17 & $104,809.80$ & 411052.05 & 104.81 & 41.11 \\
\hline $\begin{array}{l}\text { TOTAL (NON- } \\
\text { HOUSEHOLDS) }\end{array}$ & $(9,426.25)$ & $(51,146.97)$ & $(3,440.581 .2)$ & $(18,668,644.05)$ & $(3,440.58)$ & $(1866.86)$ \\
\hline TOTAL & $85,150.09$ & $362,456.09$ & $31,079,782.80$ & $132,296,472.80$ & $31,079.78$ & 13229.65 \\
\hline
\end{tabular}

Figures 3 and 4 present the annual contribution of the households in solid wastes generation expressed in percent by weight and in percent by volume. As shown, the households are the key components in making efficient SWM plan. This information can be utilized to strategize approaches for sustainable solid waste management plan. Currently, waste management activities particularly recycling and composting were not practiced by most households in the community. The challenge of cost-effective and efficient instruments to manage household waste generations has been a main concern in policy making. To undertake the challenge, the knowledge of the people on the proper waste disposal and their attitudes and preference regarding waste management systems are important in 
developing sustainable waste management strategies. The accomplishment of the waste management policy in urban areas depends to a large extent on the acceptance of the residents (Ezebilo \& Animasaun, 2011).

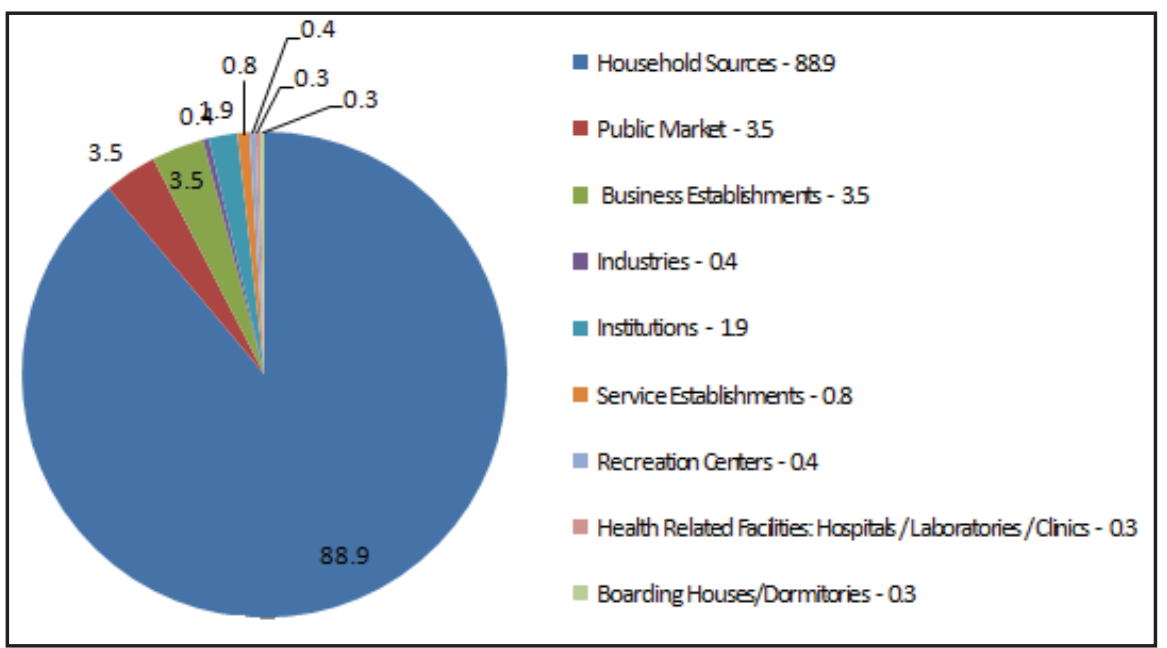

Figure 3. Projected annual percentage contribution of solid wastes by weight $(\mathrm{kg})$ from generators.

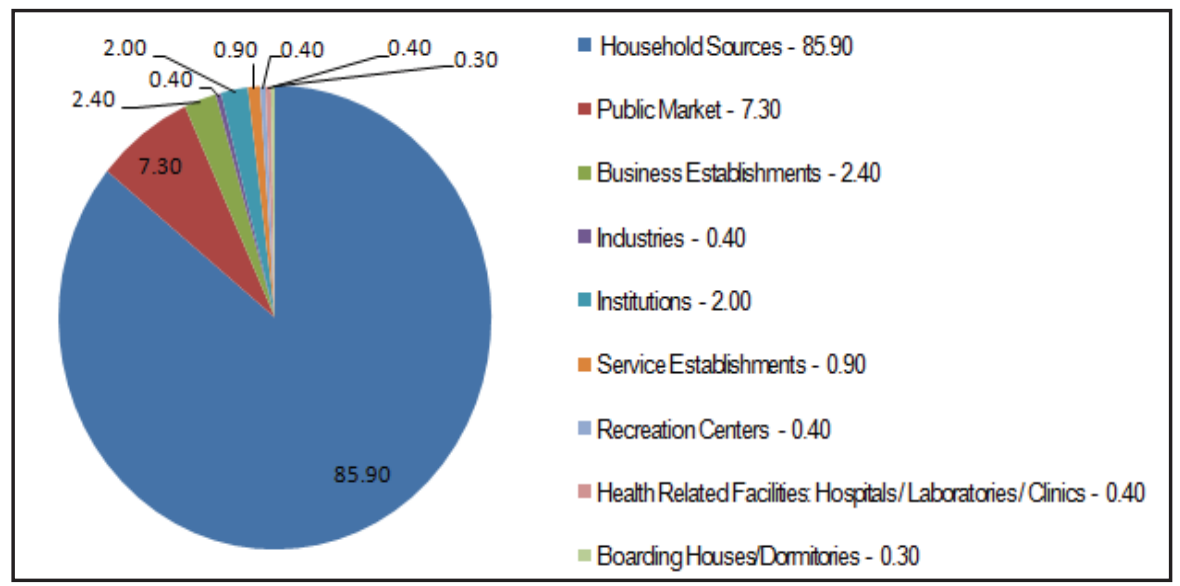

Figure 4. Projected annual percentage contribution of solid wastes by volume $(\mathrm{L})$ from generators. 
Furthermore, Table 6 shows the mathematical projection of average household solid waste generation by weight and by volume for the next ten years. Based on the percent population growth, by the year 2022, Ozamiz City will be able to accumulate approximately, $301,084.80$ tons $\left(123,779.31 \mathrm{~m}^{3}\right)$ of wastes from household sources. If the city cannot fully implement the 3 Rs (reduce, recycle and reuse), all these wastes will be buried in the dumpsites or landfills. In developing countries, authorities tend to overlook the significance of waste minimization strategies, leading to situations where all "wastes" are sent to dumpsites for final disposal (Oteng-Obabio, 2010). The traditional method of waste disposal with marginal inclusion of modern convenience appears to be the common practice (Abduli \& Nasrabadi, 2007). The existing municipal MSWM system still adopts unsegregated collection and permits open dumping which promotes scavenging activity (Abduli \& Nasrabadi, 2007).

\section{Table 6. Mathematical projection of average household solid waste} generation, by weight and volume, for ten years (2013-2022).

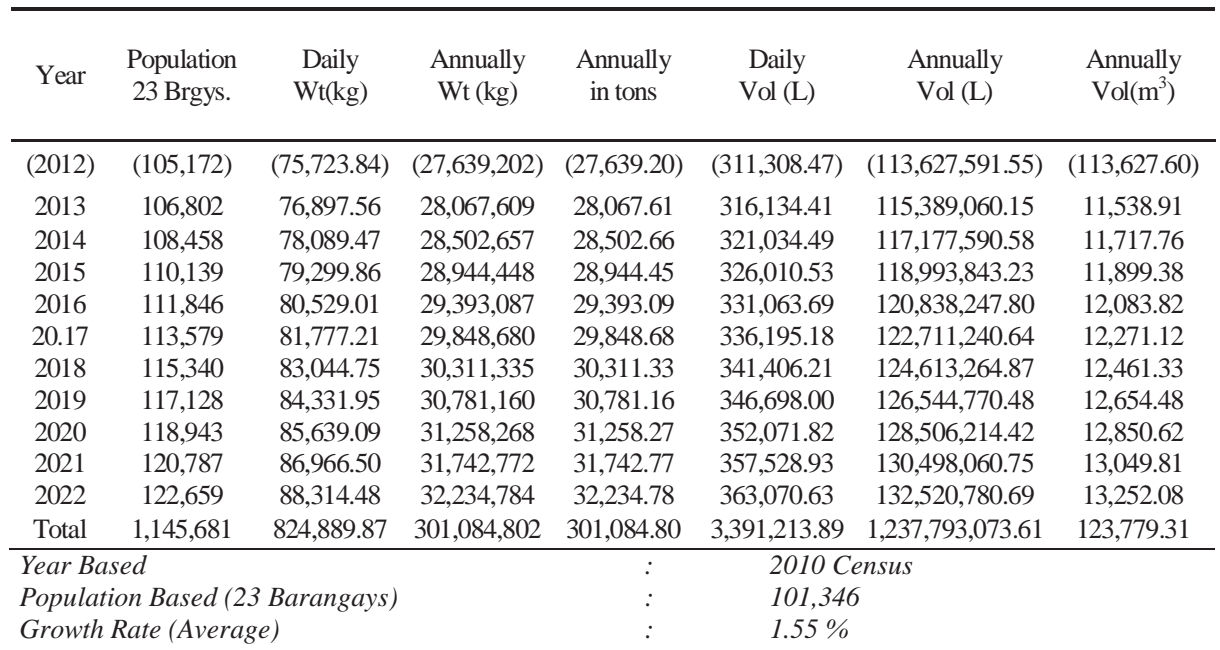

Table 7 shows the projection of average solid wastes generation of nonhousehold sources, expressed in weight and volume. By the year 2022, the city will accumulate 53,829.57 tons equivalent to $29,208.01 \mathrm{~m}^{3}$ of solid wastes from nonhousehold sources. Adding this value to the household waste accumulation makes the total of $354,914.37$ tons, which occupy a volume equal to $152,987.32 \mathrm{~m}^{3}$. Such 
huge amount of wastes poses health hazard and negative environmental impact.

These findings can be utilized to develop sustainable solid waste management programs. In 2004, Vigan City used the state-ofthe-art facility to reuse, recycle and recover waste generated solid waste management projects and provided livelihood project from wastes to poor families in the city. Organic fertilizers from wastes were given to farmers for free and housewives earned additional income by converting solid wastes to pillows and souvenir items (Bajet et al., 2012). In this regard, sustainable solid wastes management can be achieved if the issues on the lack of awareness, technical knowledge, legislation policies, and strategies (Environmental Management Centre, 2007) can be adequately addressed.

Table 7. Mathematical projection of average non-household solid wastes generation, by weight and volume, for ten years (2013-2022).

\begin{tabular}{|c|c|c|c|c|c|c|}
\hline Year & $\begin{array}{c}\text { Daily } \\
\mathrm{Wt}(\mathrm{kg})\end{array}$ & $\begin{array}{l}\text { Annual } \\
\mathrm{Wt}(\mathrm{kg}) \\
\end{array}$ & $\begin{array}{c}\text { Annual } \\
\text { Wt (tons) }\end{array}$ & $\begin{array}{c}\text { Daily } \\
\text { Vol (L) }\end{array}$ & $\begin{array}{l}\text { Annual } \\
\text { Vol (L) }\end{array}$ & $\begin{array}{c}\text { Annual } \\
\text { Vol }\left(\mathrm{m}^{3}\right)\end{array}$ \\
\hline (2012) & $(9,426.25)$ & $(3,440,581.30)$ & $(3,440.58)$ & $(51,146.97)$ & $(18,668,644.05)$ & $(1,866.86)$ \\
\hline 2013 & $10,180.35$ & $3,715,827.75$ & $3,715.83$ & $55,238.73$ & $20,162,135.57$ & $2,016.21$ \\
\hline 2014 & $10,994.78$ & $4,013,093.97$ & $4,013.09$ & $59,657.83$ & $21,775,106.42$ & $2,177.51$ \\
\hline 2015 & $11,874.36$ & $4,334,141.49$ & $4,334.14$ & $64,430.45$ & $23,517,114.93$ & $2,351.71$ \\
\hline 2016 & $12,824.31$ & $4,680,872.81$ & $4,680.87$ & $69,584.89$ & $25,398,484.13$ & $2,539.85$ \\
\hline 2017 & $13,850.25$ & $5,055,342.63$ & $5,055.34$ & $75,151.68$ & $27,430,362.86$ & $2,743.04$ \\
\hline 2018 & $14,958.27$ & $5,459,770.04$ & $5,459.77$ & $81,163.81$ & $29,624,791.89$ & $2,962.48$ \\
\hline 2019 & $16,154.94$ & $5,896,551.64$ & $5,896.55$ & $87,656.92$ & $31,994,775.24$ & $3,199.48$ \\
\hline 2020 & $17,447.33$ & $6,368,275.78$ & $6,368.28$ & $94,669.47$ & $34,554,357.26$ & $3,455.44$ \\
\hline 2121 & $18,843.12$ & $6,877,737.84$ & $6,877.74$ & $102,243.03$ & $37,318,705.84$ & $3,731.87$ \\
\hline 2022 & $20,350.57$ & $7,427,956.87$ & $7,427.96$ & $110,422.47$ & $40,304,202.30$ & $4,030.42$ \\
\hline Total & $147,478.28$ & $53,829,570.82$ & $53,829.57$ & $800,219.28$ & $292,080,036.44$ & $29,208.01$ \\
\hline $\begin{array}{l}\text { Based } \\
\text { Annuc }\end{array}$ & ase & & $:$ & $\begin{array}{l}2012 \\
8.0 \%\end{array}$ & & \\
\hline
\end{tabular}

The total amount of wastes, from household and nonhousehold sources, which will accumulate in ten years, will reach $354,914.37$ tons, equivalent to $152,987.32 \mathrm{~m}^{3}$. However, should waste reduction, re-use, recycle and composting mechanisms be implemented through the efforts of the local government and Ozamiz City Solid Waste Management Board (OCISWB), about 
$186,684.96$ tons $(354,914.37$ tons $\times 52.60 \%)$ equivalent to 64147.58 $\mathrm{m}^{3}\left(152,987.32 \mathrm{~m}^{3} \mathrm{x} 41.93 \%\right)$ biodegradable wastes will be directed to the composting facility. The recyclable materials, amounting to 47203.61 tons $(354,914.37$ tons $x 13.30 \%)$ or $42545.77 \mathrm{~m}^{3}(152,987.32$ $\mathrm{m}^{3} \times 27.81 \%$ ) can be transported to the corresponding recycling plant for processing and storage.

\section{Conclusion and Recommendations}

The current status of solid wastes in the area showed that huge amount of biodegradable wastes were generated by the households. Proper segregation should be strictly implemented to facilitate proper treatment of wastes. The results of this study can be used in establishing a comprehensive and sustainable Solid Waste Management (SWM) Plan which requires appropriate strategies and mechanics in addressing pertinent problems. Moreover, the information obtained will reinforce decision making in choosing appropriate physical facilities for collection, storage, processing and disposal and also aid in the preparation of information, education and communication (IEC) materials. Strict compliance of the 3Rs (reduce, reuse and recycle) is essential, and the "pay as you generate" principle would make the public mentally and financially committed to the maintenance of a clean and healthy environment.

\section{Acknowledgment}

The authors are grateful to the Misamis University President Dr. Karen Belina F. De Leon for allowing the manpower from the offices of Misamis University Community Extension Program (MUCEP), Misamis University Research Center (MURC), and the College of Arts and Sciences (CAS) during sampling. The authors acknowledge the City Mayor, Hon. Nova Princess Parojinog-Echavez for spearheading this project. Special thanks are given to all Ozamiz City General Services Personnel, garbage collectors and street sweepers, for their diligence and perseverance during data collection. Residents, establishment owners and head of the different private and the public agencies are also acknowledged for their involvement. 


\section{Literature Cited}

Abduli, M. A., \& Nasrabadi, T. (2007). Municipal solid waste management in Kurdistan Province, Iran. J Environ Health, 69(7), 51-5.

Al-Khatib, I. A., Monou, M., Abu Zahra, A. S., Shaheen, H. Q., \& Kassinos, D. (2010). Solid waste characterization, quantification and management practices in developing countries. A case study: Nablus district - Palestine. Journal of Environmental Management, 91(5), 1131-8. doi: 10.1016/j.jenvman.2010.01.003

Artajo, E. A. (2007). Welcome to the City of Ozamiz -Profile. The Daily Depolognon. Retrieved from http://ozamizcity.com/City Profile.htm

Bajet, M. A., Arce, G. R., Soria, J. R., Bermio, J. B. Paz, C. B., \& Bajet, JB. (2012). Solid Waste Management practices in Vigan City, Ilocos Sur, Philippines. IAMURE International Journal of Ecology. 3. doi: http://dx.doi.org/10.7718/ijec.v3i1.326

Briones, R. P. (2011). Waste analyses and characterization study (WACS) for the development of material resource and energy/ biomass/ wasteto- energy facilities using municipal solid wastes. Greenery Solutions, Inc. Retrieved from http://www.slideshare.net/ ruth00035/wasteanalyses-and-characterization-study-wacs-for-wte-project-greenergysolutions

Carey, P. (2000). Landfill manuals landfill site design. In G. Carty (Ed.). Ireland: Environmental Protection Agency. Retrieved from http://www.epa.ie/pubs/advice/licensee/epa\%20landfill\%20site\%20de sign.pdf

DENR (Department of environment and Natural Resources). (2001). DENR Administrative Order No. 2001 - 34; Implementing Rules and Regulations of Republic Act 9003 Retrieved from http://abernales. com/dao2001-34.htm

Ezebilo, E. E., \& Animasaun, E. D. (2011). Households' perceptions of private sector municipal solid waste management services: A binary choice analysis. Int J Environ Sci Technol, 8(4), 677-686. 
Environmental Management Centre. (2007). Solid waste management: issues and challenges in Asia. Report of the APO Survey on SolidWaste Management 2004-05. Retrieved from http://www.apotokyo.org/publications/files/ind-22-swm.pdf

Haider, I., Haider, M., \& Badami. M., (2013). Household Solid Waste Generation in Urban Pakistan: A Case Study of Rawalpindi. Social Science Research Network. doi.org/10.2139/ssrn.2258903

IETC (International Environmental Technology Centre). (2010). Waste and Climate Change: Global trends and strategy framework. United Nations Environmental Programme (UNEP). Retrieved from http://www.unep.or.jp/ietc/Publications/spc/Waste\&ClimateChange/ Waste \& Climate Change

McCormack, K. (2004). Waste Management Report. Shire of Plantagenet. Retrieved from http://www.lgnet.com.au/plant.nsf/ 67cb64034472bf0448256c2200241cb6/8d7a0275fd415cfc48256e6c0 $05442 \mathrm{c} 3$

Nasrabadi, T., Hoveidi, H., Bidhendi, G. N., Yavari, A.R., \& Mohammadnejad, S. (2008). Evaluating citizen attitudes and participation in solid waste management in Tehran, Iran. $J$ Environ Health, 71(5), 30-3, 39-40.

Naz, A. C., \& Naz, M. C. (2008). Ecological solid waste management in suburban municipalities. Journal of Southeast Asian Economies, 25(1). Retrieved from http://www.questia.com/library/journal/1G1 183423022/ecological-solid-waste-management-in-suburbanmunicipalities

NSO. (2013). Population of Misamis Occidental Showed an Increase of 81 Thousand in 10 Years (Results from the 2010 Census of Population and Housing). Republic of the Philippines National Statistics Office. Retrieved from http://www.census.gov.ph/ content/population-misamis-occidental-showed-increase-81thousand-10-years-results-2010-census 
Oeltzschner, H., \& Mutz, D. (1994). Guidelines for an appropriate management of domestic sanitary landfill sites. Deutsche Geselischaft für Technische Zusammenarbeit (GTZ) GmbH.] -Rossdorf. Retrieved from https://ph- mg61.mail.yahoo. com/neo/launch?.rand=3u7no dqh8730h\#

Ogbonna, D. N., Amangabara, G. T., \& Ekere, T. O. (2007). Urban solid waste generation in Port Harcourt metropolis and its implications for waste management. Management of Environmental Quality, 18(1), 71-88. doi:10.1108/147778307 10717730

Oteng-Obabio, M. (2010). Waste Management and Research. SAGE, 322329. Retrieved from http://ugspace.ug.edu.gh/handle/123456 789/ 2488

Ramachandra, T. V., \& Bachamanda, S. (2007). Environmental audit of municipal solid waste management. International Journal of Environmental Technology and Management, 7, 369-391. Retrieved from http://inderscience.metapress.com/content/fg3u2 38444157t74/

Rasi, S., Veijanen, A., \& Rintala, J. (2007). Trace compounds of biogas from different biogas production plants. Energy, 32(8), 1375-1380

Sagapolutele, F., \& Rasch, K. (2008). Solid waste generation \& characterization surveys, Upolu \& Savaii. Secretariat of the Pacific Regional Environment Program (SPREP). Retrieved from http://www.sprep.org/att/irc/ecopies/countries/samoa/203

US EPA (United States Environmental Protection Agency). (1996). The Consumer's Handbook for Reducing Solid Waste, p.7. Retrieved from http://www.epa.gov/osw/conserve/downloads /cat96.pdf

Vasanthi, P., Kaliappan, S., \& Srinivasaraghavan, R. (2008). Impact of poor solid waste management on ground water. Environ Monit Assess., 143(1-3), 227-38. Retrieved from http:// www .ncbi. nlm. nih.gov/pubmed/17999155 